\title{
Development of a Questionnaire for Recruiting and Pre-Selecting Candidates for the Hotel, Restaurant and Catering Sector (HORECA-5)
}

\author{
${ }^{1}$ Jordi Tous-Pallarès, ${ }^{2}$ Cinthya Camila Merma Linares, ${ }^{3}$ Solángel Alejandra Brijaldo \\ Moreno, ${ }^{4}$ Anna Paulina Pazdyka \\ 1,2,3 Psychology Department, RoviraiVirgili University, Tarragona, Spain \\ ${ }^{4}$ University of Kazimierz Wielki (Poland), Department of Social Psychology, Faculty of Pedagogy \\ and Psychology
}

\begin{abstract}
This article describes the process by which the HORECA-5 questionnaire was drawn up to improve recruitment management and candidate selection in the hospitality sector. The questionnaire can be used to select personnel since it takes into account not only the technical abilities of the candidates but also five indicators of the key competencies for successful performance: Teamwork (TW), Customer Orientation $(\mathrm{CuO})$, Work Organization (WO), Resistance to Stress/Problem Solving (PS) and Initiative/autonomy (IA). The empirical work was carried out with a sample of 12 recruitment managers and 177 employees currently working in the hospitality sector on the Mediterranean coast in Catalonia (Spain).
\end{abstract}

The results show that the psychometric properties of the HORECA-5 questionnaire are acceptable and that it has a single-factor structure. The questionnaire objectively determines the skills, competencies and personality traits that candidates should have if they are to perform their duties successfully.

Keywords: skills, competencies, recruitment and personnel selection

\section{INTRODUCTION}

The hospitality, restaurant and catering sector (HORECA) is constantly having to evolve and adapt to the increasing diversity of products and the ever-growing demands for quality by customers. If the sector is to be competitive, it must be able to rely on competent professionals who can perform their professional duties to high levels of excellence (Tous-Pallarès, 2009; 2011). However, candidates for operational positions in the HORECA sector are often selected without taking into account important traits and variables (personality, attitudes, competencies and personal motivation) that can be used to predict their job performance (Gorriti, 2006; Tous-Pallarès, Tendero\& González-Massot, 2008).

To make the sector attractive and provide quality service, the vision of human resources needs to be strategic and comprehensive (Salgado \&Mocoso, 2008). It is difficult to find employees with talent if recruitment and selection is carried out in the traditional way (Hunter \& Hunter, 1984; Schmidt, Ones \& Hunter, 1992; Hunter \& Schmidt, 2004): that is to say, the basic criterion for selection is the information the candidates themselves give in their CV about their education, training and professional experience. In some cases, personal interviews are used to supplement the initial information or to help rank the candidates regarded as being most suitable for the job (Pérez, Mora\& Sotomayor, 2007).

To avoid the subjectivity of interviews and traditional methods, Salgado \&Moscoso (2008) propose using the structured behavioural interview (SBI) as a source of objective information about key competencies for a particular job. It is a technique based on identifying observable and relatively stable indicators that are related to good, quality performance. The behavioural indicators improve predictive capacity because they specify the various degrees of skill and competence required for each job (Salgado, 2005). What is more, the Critical Incident Technique (CIT) (Flanagan, 1954) can be used to determine the key competencies $(\mathrm{KC})$ related to job performance.

SBIs use a list of key observable behaviours to determine what employees know (knowledge), what they know how to do (skills) and their attitudes to quality performance in the workplace. 
Rojon, McDowall \& Saunders (2015) suggest that various competencies are key to performance in the hospitality sector: for example, flexibility, self-control, teamwork, customer orientation, quality of the service, outcome orientation. Although these variables are part of the job descriptions in the sector, they are often not assessed in the initial stages of selection (Martínez\& Castro, 2010).

Neither do selection processes always take into account personality traits directly related to performance, low-quality service or a tendency to absenteeism (Tous-Pallarès, 2009). Therefore, personality types A or B, impulsivity or social desirability (Salgado, 2005) are traits based on the "Big Five" models for determining the competence and suitability of candidates for holding down a job in HORECA. Berkelaar (2014), Berkelaar \& Buzzanell (2014) suggest that the resources offered by these new methodologies need to be used to combine information about key competencies (KC) and personality traits in processes of recruitment and pre-selection of candidates in the HORECA sector.

\section{METHOD}

\subsection{Participants}

The present study used two samples. The first was used to identify critical incidents (CI). It was made up of those responsible for selecting personnel in 12 hotels in the tourist area of Catalonia (Spain). The second sample was used to analyse the psychometric properties of the scale and consisted of 177 employees holding operational positions in the HORECA sector. A total of 52\% of the sample were women and $48 \%$ men. Also, $36.8 \%$ had only a basic education, $43.7 \%$ had a secondary or preuniversity education and $19.5 \%$ had completed a course of higher education.

\subsection{Instruments}

The scale used was the Overall Personality Assessment Scale (OPERAS) (Vigil-Colet, MoralesVives, Camps, Tous-Pallarès\& Lorenzo-Seva, 2013). It consists of 40 items that measure personality traits on the basis of the Big Five model: Extraversion (EX), Emotional stability (ES), Conscientiousness (CO), Agreeableness (AG) and Openness (OP). It has good convergent validity with the other commonly used personality measures. The reliability of the five factors is acceptable: $\mathrm{EX}(a=.86), \mathrm{ES}(a=.86), \mathrm{CO}(a=.77), \mathrm{AG}(a=.71)$ and $\mathrm{OE}(a=.81)$.

\subsection{Procedure}

In the first stage the key skills and competencies for each one of the 7 professional groups in the HORECA sector and the 19 most common operational positions were defined. With the information provided, the summary table below was drawn up (see table 1).

Table1. Classification of professional groups and operational positions in the HORECA sector

\begin{tabular}{|l|l|l|l|l|}
\hline $\begin{array}{l}\text { Operational position in } \\
\text { HORECA }\end{array}$ & Level 1 & Level 2 & Level 3 & Level 4 \\
\hline Kitchen & Busboy & Assistant & Chef & Supervisor \\
\hline Restaurant / Buffet & & Assistant & Waitress & Team Leader \\
\hline Cafeteria / Bar & & Assistant & Supervisor & \\
\hline Rooms & & Chambermaid/ Maid & Supervisor & \\
\hline Reception & & Assistant & Supervisor & \\
\hline Administration / Management & & Administrative & Supervisor & Director \\
\hline Assistants & Watchman & Maintenance & Supervisor & \\
\hline
\end{tabular}

In the second stage the critical incidents (CI) for each of the 19 jobs documented (table 1) were identified. Structured behavioural interviews (SBI) were held with the people responsible for recruiting personnel at the sample hotels to collect information about the behaviours that define correct and incorrect performance in each group of jobs. This information was discussed by a group of experts and the key competencies related to observable successful job performance were identified.

On the basis of the CIs identified, the 26 items of the HORECA-5 questionnaire were drafted and organised into two blocks of questions. The first consisted of 15 items that give demographic and basic CV information. The second consisted of 11 items that assess five key competencies related to appropriate job performance. For each item, there were three response options (appropriate performance, neutral performance and inappropriate performance).

In the third stage, the HORECA-5 questionnaire was administered together with the OPERAS questionnaire to 177 employees in the hotel sector to evaluate its psychometric properties. The results 
Development of a Questionnaire for Recruiting and Pre-Selecting Candidates for the Hotel, Restaurant and Catering Sector (HORECA-5)

of the questionnaires were subject to statistical analysis using the statistical package SPSS v.20 (Nouri, 1999) and the FACTOR program v. 9.31 (Lorenzo-Seva \& Ferrando, 2013).

\section{RESUlTS}

\subsection{Development of the Questionnaire: Identification of Competencies and Drafting of Items}

The analysis of the job descriptions in the first stage enabled us to determine a matrix structure of five key competencies, which were used as a selection criterion by the hotels. The competencies identified were regarded as "key competencies" (KC) for all the categories of HORECA jobs (kitchen, restaurant, bar, rooms, reception, administration and assistants).

The key competencies (KC) were correlated with a list of characteristic behaviours of performance and critical incidents drawn from the analysis of the structured behavioural interviews with those responsible for recruiting personnel in the hotels. Table 2 shows theresults of theSBIs.

Table2.Matrix of competencies and positions for purposes of personnel recruitment, selection and training in HORECA

\begin{tabular}{|c|c|c|c|c|c|c|c|}
\hline \multirow[t]{2}{*}{ Competencies } & \multicolumn{7}{|c|}{ Departments in HORECA } \\
\hline & Kitchen & Restaurant & $\underline{\text { Bar }}$ Service & $\begin{array}{l}\text { Room } \\
\text { Service }\end{array}$ & Reception & Administration & Assistance \\
\hline $\begin{array}{l}\text { (CO) Customer } \\
\text { orientation }\end{array}$ & & & $\mathrm{X}$ & $\mathrm{X}$ & $\mathrm{X}$ & $\mathrm{X}$ & \\
\hline (OT) Organization & $\mathrm{X}$ & $\mathrm{X}$ & $\mathrm{X}$ & $\mathrm{X}$ & $\mathrm{X}$ & $\mathrm{X}$ & $\mathrm{X}$ \\
\hline \multirow{2}{*}{$\begin{array}{l}\text { (TE) Teamwork } \\
\text { Coordination of } \\
\text { teams }\end{array}$} & $\mathrm{X}$ & $\mathrm{X}$ & $\mathrm{X}$ & $\mathrm{X}$ & $\mathrm{X}$ & $\mathrm{X}$ & \\
\hline & $\mathrm{X}$ & $\mathrm{X}$ & & $\mathrm{X}$ & $\bar{X}$ & $\mathrm{X}$ & \\
\hline \multirow{2}{*}{$\begin{array}{l}\text { (PS/RS)Problem- } \\
\text { solving/Resistance } \\
\text { to stress }\end{array}$} & & & & & $\mathrm{X}$ & $\mathrm{X}$ & \\
\hline & $\mathrm{X}$ & $\mathrm{X}$ & & & $\mathrm{X}$ & & \\
\hline \multirow{2}{*}{$\begin{array}{l}\text { (AI)Autonomy/ } \\
\text { Initiative }\end{array}$} & & & $\mathrm{X}$ & $\mathrm{X}$ & & $\mathrm{X}$ & $\mathrm{X}$ \\
\hline & & & & & $\mathrm{X}$ & $\mathrm{X}$ & \\
\hline
\end{tabular}

\subsection{Psychometric Properties of the Questionnaire: EFA, Reliability and Validity}

The analysis of the HORECA-5 scale shows a total reliability of $(a=.751)$. The reliability of each dimension was $a=.603$ for Teamwork (TW), $a=.314$ for Customer Orientation (CuO), $a=.419$ for Work Organization (OT), $a=.501$ for Resistance to Stress and Problem Solving (RS/PS) and $a=.424$ for Initiative/Autonomy (IA). These results are presented in table 3 and suggest that future work should use raw scores to calculate the dimensions.

Table3. Reliability analysis of critical incidents in the HORECA-5 scale

\begin{tabular}{|c|l|l|l|l|l|}
\hline & \multicolumn{1}{|c|}{ Item } & $\begin{array}{l}\text { Scale mean } \\
\text { if item } \\
\text { deleted }\end{array}$ & $\begin{array}{l}\text { Scale } \\
\text { variance if } \\
\text { item deleted }\end{array}$ & $\begin{array}{l}\text { Squared } \\
\text { Multiple } \\
\text { Correlation }\end{array}$ & $\begin{array}{l}\text { Cronbach's } \\
\text { alpha if item } \\
\text { deleted }\end{array}$ \\
\hline 1. & $\begin{array}{l}\text { You are in a team and you have } \\
\text { goals to achieve during the day. } \\
\text { Your shift is ending and none of } \\
\text { the goals have been achieved. } \\
\text { What do you do? }\end{array}$ & 21.67 & 19.767 & .578 & .710 \\
\hline 2. & $\begin{array}{l}\text { Have you ever had a conflict with } \\
\text { a team member at work? }\end{array}$ & 22.41 & 20.369 & .310 & .749 \\
\hline 3. & $\begin{array}{l}\text { When you work alone, do you } \\
\text { obtain better results than when } \\
\text { you work in a team? }\end{array}$ & 22.27 & 19.801 & .397 & .734 \\
\hline 4. & $\begin{array}{l}\text { You have a customer who is } \\
\text { interested in a service provided } \\
\text { by the hotel, but eventually he } \\
\text { says that he does not have enough } \\
\text { money to pay. What do you do? }\end{array}$ & 22.99 & 22.614 & .222 & .751 \\
\hline 5. & $\begin{array}{l}\text { Would you adapt your service } \\
\text { strategies to a customer's } \\
\text { nationality, age or purchasing } \\
\text { power? }\end{array}$ & 22.20 & 20.902 & .520 & \\
\hline
\end{tabular}


Jordi Tous-Pallarès et al.

\begin{tabular}{|c|c|c|c|c|c|}
\hline 6. & $\begin{array}{l}\text { Do you usually achieve the goals } \\
\text { that you set yourself? }\end{array}$ & 22.02 & 21.738 & .360 & .738 \\
\hline 7. & $\begin{array}{l}\text { After setting an objective, do you } \\
\text { plan your work (tasks to be } \\
\text { performed every day or during } \\
\text { the week, etc.)? }\end{array}$ & 21.79 & 19.999 & .482 & .721 \\
\hline 8. & $\begin{array}{l}\text { What have you done in stressful } \\
\text { situations when you have had a } \\
\text { lot of work, and you've not } \\
\text { known what to do, but have } \\
\text { needed to meet your goals? }\end{array}$ & 22.02 & 19.755 & .529 & .715 \\
\hline 9. & $\begin{array}{l}\text { When you have a complex } \\
\text { problem, what do you do to solve } \\
\text { it? }\end{array}$ & 22.21 & 20.871 & .257 & .757 \\
\hline 10. & $\begin{array}{l}\text { How have you dealt with a } \\
\text { problem that has so overwhelmed } \\
\text { you that you have been unable to } \\
\text { take action? }\end{array}$ & 22.50 & 21.490 & .397 & .734 \\
\hline 11. & $\begin{array}{l}\text { Do you think a lot before making } \\
\text { decisions? }\end{array}$ & 21.87 & 20.455 & .464 & .724 \\
\hline
\end{tabular}

To explore the factor structure of the HORECA-5 questionnaire, we used the FACTOR program (Lorenzo-Seva\&Ferrando, 2006) to apply Exploratory Factor Analysis (EFA) to the 11 items. The Kaiser-Meyer-Olkin statistic was .52, which was regarded as low and within the limits of the cut-off point (Kayser, 1970). Theoptimal implementation of parallel analysis procedure (Timmerman \& Lorenzo-Seva, 2011) was used to determine the number of factors of the scale and minimum rank factor analysis (MRFA) (Ten Berge \& Kiers, 1991). The scale was found to be unidimensional.

Table4. Factor analysis results of the sample $(N=177)$ obtained through AFE

\begin{tabular}{|l|l|l|}
\hline Ítem & F1 & Communality \\
\hline 1. & $\mathbf{. 1 2 6}$ & $\mathbf{. 2 8 7}$ \\
\hline 2. & -.018 & .159 \\
\hline 3. & .237 & .320 \\
\hline 4. & $\mathbf{. 3 8 5}$ & .397 \\
\hline 5. & .256 & .396 \\
\hline 6. & $\mathbf{. 3 7 2}$ & .299 \\
\hline 7. & -.110 & .264 \\
\hline 8. & $\mathbf{. 1 4 7}$ & .387 \\
\hline 9. & $\mathbf{- . 8 3 3}$ & .927 \\
\hline 10. & -.195 & .248 \\
\hline 11. & -.272 & .466 \\
\hline
\end{tabular}

The lowest value is for item 2 (.006). The highest value is for item 9 (.927). The loadings are high (above .25 and below -.25 ) for items $4,6,7$ and 9. The total variance explained by the single factor was .833 . The total variance explained by the factor was 1.264 (which is $30.46 \%$ of the total common variance. Table 4 shows communality values between .159 and .927 . The highest loadings (above .30 and below -30) were found for items 4, 6 and 8 .

Table5. Matrix of correlations between OPERAS variables and the general HORECA-5 score

\begin{tabular}{|l|l|l|l|l|l|}
\hline & EX & ES & CO & AG & OE \\
\hline TE & .089 & $\mathbf{. 1 5 7}^{*}$ & .090 & $\mathbf{. 1 6 8}^{*}$ & .102 \\
\hline $\mathrm{CuO}$ & -.064 & -.064 & .051 & .083 & .051 \\
\hline OT & -.091 & -.146 & -.027 & .006 & -.011 \\
\hline PS/RS & .017 & .141 & $\mathbf{. 2 0 6}$ & .033 & $\mathbf{. 1 9 2}^{* *}$ \\
\hline IA & -.089 & -.063 & -.019 & -.010 & -.050 \\
\hline
\end{tabular}

EX: Extraversion; AG: Agreeableness; CO: Conscientiousness; ES: Emotional stability; OE: Openness to experience; TE: Teamwork; CuO: Customer Orientation; OT: Organization; PS/ RS: Problem-Solving/ Resistance to Stress; AI: Autonomy/ Initiative.

*Statistically significant differences at $p=.05$. ** Statistically significant differences at $p=.01$

Table 5 shows the matrix of correlations calculated with the scores from the two questionnaires (HORECA-5 and OPERAS). The correlations are significant between the general score of the 
HORECA-5 scale and the scores of some of the five OPERAS factors (Teamwork with Emotional Stability [ $\mathrm{r}=.157]$ and Agreeableness [ $\mathrm{r}=.168]$; Resistance to Stress and Problem Solving with Conscientiousness $[\mathrm{r}=.206]$ and Openness [r= .192]. However, the effect sizes between variables are low to moderate.

\section{ConClusions}

This study has empirically determined the usefulness of SBIs for identifying CIs and KCs in jobs in the HORECA sector. The Critical Incident Technique is very useful for extracting the information obtained with the SBIs. A total of five key competencies were identified that were common to all jobs in the HORECA sector: Teamwork, Customer Orientation, Organization, Resistance to Stress and Problem Solving, and Initiative/Autonomy, the same as the ones identified by Rojon, McDowall \& Saunders (2015).

Using this information to draw up HORECA-5 improves the criteria for selecting candidates since the questions focus on the competencies that are key to successful job performance, as was pointed out by Pérez, Mora\& Sotomayor (2007) and Salgado (2005). The questionnaire applies the comprehensive, strategic vision of human resources (Salgado \&Moscoso, 2008) to the recruitment of candidates with the greatest potential, and replaces traditional recruitment techniques (Hunter \& Hunter, 1984; Hunter \& Schmidt, 2004) with tests based on key competencies.

Although the overall reliability of the HORECA-5 questionnaire is acceptable $(a=.75)$, it is not good enough for it to be used in personnel selection processes as a single criterion for choice, which would require a reliability of above .80 (Nunnally, 1989). The scale's unidimensional structure does not enable us to do more than analyse the matrix of correlations between the dimensions of the HORECA-5 scale.

Finally, the dimensions of HORECA-5 show weak positive correlations with the personality factors of the OPERAS test, which indicates that there is little relationship between personality traits and the key competencies required for the job. Even so, this low correlation, which is not found in other studies consulted, may be explained by the small size of the sample (Gorriti, 2006; Tous-Pallarès, Tendero\& González-Massot,2008).

\section{ACKNOWLEDGEMENTS}

This work was supported by Asociación Hotelera Salou - Cambrils - Playas de La Pineda (AHSCPLP), URV Foundation and Santander BankProject /2014 LINE 12.

\section{REFERENCES}

Berkelaar, B. L. (2014). Cybervetting, Online Information, and Personnel Selection New Transparency Expectations and the Emergence of a Digital Social Contract. Management Communication Quarterly. 28 (4), 479-506. doi: 10.1177/ 0893318914541966.

Berkelaar, B. L., \&Buzzanell, P. M. (2014). Online Employment Screening and Digital Career Capital Exploring Employers' Use of Online Information for Personnel Selection. Management Communication Quarterly. 29 (1), 84-113. doi 10.1177/0893318914554657.

Flanagan, J.C. (1954). "The Critical Incident Technique". PsychologicalBulletin, 51 (4), 327-358.

Gorriti, M. (2006). La evaluación del desempeño: concepto, criterios y método. Dirección de Función Pública del Gobierno Vasco.

Hunter, J. E., \& Hunter, R. F. (1984). Validity and utility of alternative predictors of jobs performance. Psychological Bulletin. 96 (1), 72-98. Doi: 10.1037/00332909.96.1.72

Hunter, J. E., \& Schmidt, F. L. (2004). Methods of meta-analysis: Correcting error and bias in research findings. Thousand Oaks, California: Sage.

Lorenzo-Seva, U., \&Ferrando, P. J. (2013). FACTOR 9.2: A Comprehensive Program for Fitting Exploratory and Semiconfirmatory Factor Analysis and IRT Models. Applied Psychological Measurement. 37 (6), 497-498.

Martínez, F. J. T., \& Castro, J. C. R. (2010). La supuesta neutralidad de la evaluación por competencias. RIO: Revista Internacional de Organizaciones, (5), 109-126.

Nouri, M.J. (1999) SPSS for Windows 9.0. Chicago: SPSS Inc. 
Nunnally, (1989). Teoría psicométrica. Méjico: Trillas.

Pérez, J.A., Mora, M.M., \& Sotomayor, M. (2007) Métodos mayormente usados en la selección de personal en Puerto Rico. Revista Puertorriqueña de Psicología .18

Salgado, J.F. (2005). Personalidad y deseabilidad social en contextos organizacionales: implicaciones para la práctica de la psicología del trabajo y las organizaciones. Papeles del Psicólogo. 26, 115128.

Salgado, J. F., \& Moscoso, S. (2008). Selección de personal en la empresa y las administraciones públicas: de la visión tradicional a la visión estratégica. Papeles del Psicólogo, 29(1), 16-24.

Schmidt, F.L., Ones, D.S., \& Hunter, J.E. (1992). Personnel selection. Annual Review of Psychology. 43, 627-670.

Timmerman, M. E., \& Lorenzo-Seva, U. (2011). Dimensionality Assessment of Ordered Polytomous Items with Parallel Analysis. Psychological Methods, 16, 209-220.

Tous-Pallarès, J., Tendero, LL.P., \& González-Massot, G. (2008). Promoción de la calidad de vida laboral a través del análisis del comportamiento absentista. En. Psicología de la Salud Ocupacional (2): Promoción de la Salud Ocupacional. Barcelona: Publidisa. 156-180.

Tous- Pallarès, J. (2009). Análisis del comportamiento absentista en el sector hotelero. Septem: Oviedo.

Tous-Pallarès, J. (2011) Aspectes Psicosocials de la Qualitat de Vida Laboral en el Sector Hotelero.Tarragona: Publicacions URV.

Vigil-Colet, A., Morales-Vives, F., Camps, E., Tous-Pallarès, J., \& Lorenzo-Seva, U. (2013). Development and validation of the Overall Personality Assessment Scale (OPERAS). Psicothema, 25, 100-106. 